\title{
PENERAPAN STATISTICAL QUALITY CONTROL (SQC) PADA PENGENDALIAN MUTU MINYAK TELON (STUDI KASUS DI PT.X)
}

\author{
A.L. Rucitra ${ }^{1 *}$, S. Fadiah ${ }^{1}$, \\ ${ }^{1}$ Program Studi Teknologi Industri Pertanian, Fakultas Teknologi Pertanian, \\ Universitas Brawijaya, \\ J1. Veteran, Kota Malang, Kode Pos 65145, Indonesia \\ Telp (0341) 580106 Fax : (0341) 568917 \\ *Email : andanrucitra@ub.ac.id
}

\begin{abstract}
Telon oil is one of the traditional medicine in the form of liquid preparations that serves to provide a sense of warmth to the wearer. PT.X is one of the companies that produce telon oil. To maintain the quality of telon oil from PT.X product, required overall quality control that is starting from the quality control of raw materials, quality control process to the quality control of the final product. The purpose of this research is to know the application of Statistical Quality Control (SQC) in controlling the quality of telon oil in PT X. Final product quality become one of the measurement of success of a process, so it needs a good quality control. SQC method used in this research is Pareto Diagram and Cause and Effect Diagram. Pareto diagram is a bar graph that show the problem based on the order of the number of occurrences of the most number of problems until the least happened. A causal diagram is often called a fishbone diagram, a tool for identifying potential causes of an effect or problem. The result of applying the method indicates that $80 \%$ defect is caused by unsuitable volume and on the incompatibility of Expired Date (ED) code. The damage is caused by several factors namely the method, labor, and machine while the most potential factor is the volume conformity to reduce the number of defect products.
\end{abstract}

Keyword: quality control, statistical quality control, SQC, telon oil

\section{PENDAHULUAN}

Teknologi yang semakin berkembang menuntut perusahaan untuk menciptakan produk yang berkualitas tinggi untuk dapat bersaing ditingkat global. Jamu merupakan salah satu jenis produk yang dinilai mampu bersaing ditingkat internasional. Menurut Delima dkk. (2012) jamu adalah obat tradisional yang berupa bahan atau ramuan dari tumbuhan, hewan, mineral, sediaan sarian (galenik), atau campuran dari bahan tersebut yang secara turun temurun telah digunakan untuk pengobatan, dan dapat diterapkan sesuai dengan norma yang berlaku di masyarakat. Jamu merupakan salah satu pengobatan tradisional yang mayoritasnya dikonsumsi oleh masyarakat jawa dan perkembangannya sudah mulai tersebar diindonesia. Cara penyajian jamu biasanya dengan cara merebus daundaunan obat, menumbuk, dan menggilingnya (Adi, 2013).

Salah satu produsen jamu di Indonesia adalah PT X yang telah berdiri sejak tahun 1963. Produk yang dihasilkan PT $X$ terdiri dari 3 macam yaitu obat dalam, obat luar dan minuman. Obat dalam meliputi jamu serbuk dan jamu ekstrak, obat luar meliputi param; pilis; tapel; mangir; lulur; bedak dan minyak telon serta produk minuman berbentuk minuman madu. Untuk memproduksi produk dengan kualitas kelas dunia tentunya diperlukan pengendalian serta 
standar mutu yang baik. Standar mutu harus mampu berkembang untuk meningkatkan kualitas produk yang dihasilkan. Maka, dibutuhkan suatu pengendalian mutu produk yang sesuai dengan kebutuhan perusahaan.

Dalam menjaga mutu produk minyak telon dari PT X, diperlukan pengendalian mutu secara keseluruhan yaitu mulai dari pengendalian mutu bahan baku, pengendalian mutu proses hingga pengendalian mutu produk akhir. Produk akhir yang bermutu menjadi salah satu tolok ukur keberhasilan suatu proses, sehingga diperlukan pengendalian mutu yang baik yang dapat mengarahkan konsumen untuk puas dalam mengkonsumsi produk tersebut. Sedangkan dari segi produsen dengan adanya pengendalian kualitas dapat mengurangi biaya yang terkait dengan penurunan tingkat kerusakan produk.

Sebaliknya bagi perusahaan yang tidak memperhatikan pengendalian kualitas dalam jangka panjang akan sulit untuk memasarkan produk dikarenakan persaingan dengan produk sejenis lain di pasaran yang memiliki kualitas lebih baik. Tujuan dari penelitian ini adalah untuk mengetahui penerapan Statistical Quality Control (SQC) dalam pengendalian mutu minyak telon di PT X. Metode SQC yang digunakan dalam penelitian ini adalah Diagram Pareto dan Diagram Sebab Akibat. Diagram pareto adalah sebuah grafik batang yang menunjukkan masalah berdasarkan urutan banyaknya jumlah kejadian dari jumlah permasalahan yang paling banyak terjadi sampai yang paling sedikit terjadi. Diagram sebab akibat sering juga disebut diagram tulang ikan yaitu alat untuk mengidentifikasi berbagai sebab potensial dari satu efek atau masalah.

\section{METODE}

Penelitian ini dilaksanakan di PT X. Pengolahan data dilakukan di Laboratorium Komputasi dan Analisis
Sistem Jurusan Teknologi Industri Pertanian, Fakultas Teknologi Pertanian, Universitas Brawijaya, Malang. Metode yang digunakan pada penelitian ini adalah metode Statistical Quality Control (SQC) dengan metode deskripsi analitis. Deskripisi analitis adalah penelitian yang menggambarkan suatu gambaran pada suatu kejadian kemudian dikumpulkan, disusun, dijelaskan dianalisis dan dicari hubungannya (Sumhudi, 1991).

\section{a. Prosedur Penelitian}

Penelitian ini dimulai dengan mengadakan survei dan wawancara pada PT X. Survei pendahuluan dan wawancara bertujuan untuk mengetahui kondisi sebenarnya dari perusahaan yang dapat digunakan dalam perumusan permasalahan yang ada pada perusahaan serta dapat memberikan arah yang jelas langkah-langkah yang dilakukan selanjutnya oleh peneliti. Identifikasi permasalahan yang akan diselesaikan pada penelitian ini adalah "Penerapan Statistical Quality Control (SQC) pada pengendalian mutu minyak telon". Metode SQC yang digunakan dalam penelitian ini adalah Diagram Pareto dan Diagram Sebab Akibat.

Diagram pareto adalah sebuah grafik batang yang menunjukkan masalah berdasarkan urutan banyaknya jumlah kejadian dari jumlah permasalahan yang paling banyak terjadi sampai yang paling sedikit terjadi dalam proses produksi minyak telon sedangkan Diagram sebab akibat sering juga disebut diagram tulang ikan yaitu alat untuk mengidentifikasi berbagai sebab potensial dari satu efek atau masalah pada proses pengendalian mutu minyak telon.

\section{b. Analisis Data}

\section{Bagan Kendali P}

Data terkait pengendalian mutu minyak telon diambil dari beberapa proses pengolahan minyak telon yang dilakukan oleh PT X yang merupakan atribut yang berpengaruh dengan bagan kendali $\mathrm{P}$ 
untuk data produk yang tidak sesuai standar perusahaan. Penggunaan baga kendali $\mathrm{P}$ terhadap produk cacat adalah sebagai berikut :

1. Menentukan ukuran contoh $(\mathrm{k})$

2. Menghitung nilai rata-rata produk yang cacat Jumlah produk cacat $p=\frac{(\text { tidak memenuhi standar) }}{\text { Jumlah produksi }}$

3. Simpangan baku

$$
S P=\sqrt{\frac{\bar{p}(1-\bar{p})}{k}}
$$

4. Menghitung batas kontrol

$$
\begin{aligned}
& \mathrm{CL}=\mathrm{p}^{-} \\
& \mathrm{UCL}=\mathrm{p}^{-}+3 \mathrm{SP} \\
& \mathrm{LCL}=\mathrm{p}^{-}-3 \mathrm{SP}
\end{aligned}
$$

5. Membuat bagan kendali masing masing dengan cara meplotkan data masing-masing dan dilakukan pengamatan terhadap data tersebut

\section{Diagram Pareto}

Diagram Pareto merupakan grafik batang yang menunjukkan masalah berdasarkan urutan banyaknya jumlah kejadian dari jumlah permasalahan yang paling banyak terjadi sampai yang paling sedikit terjadi. Sehingga diagram pareto adalah alat yang dapat merepresentasikan sumber defect yang paling sering ditemui, jenis kecacatan yang paling sering muncul, ataupun alasan-alasan yang paling sering muncul. Sehingga alat tersebut dapat membantu perusahaan mengidentifikasi penyebab kecacatan terbesar agar dapat dilakukan perbaikan. Diagram pareto dalam penelitian ini digunakan untuk mengetahui data kerusakan produk minyak telon dari PT X, dan kecacatan yang sering terjadi pada proses pengolahan minyak telon sehingga dapat memusatkan perhatian pada faktor yang memiliki dampak terbesar terhadap kecacatan produk.

\section{Fishbone Diagram}

Diagram tulang ikan atau Fishbone Diagram adalah salah satu metode untuk meningkatkan kualitas. Sering juga diagram ini disebut dengan diagram sebab-akibat atau cause effect diagram. Fishbone diagram (diagram tulang ikan) memiliki fungsi dalam yaitu untuk mengidentifikasi penyebab-penyebab yang kemungkinan timbul dari suatu efek spesifik. Metode ini juga digunakan menampilkan unsur-unsur yang mengakibatkan produk tidak sesuai dengan parameter mutu yang sudah ditentukan. Langkah-langkah untuk membuat diagram sebab akibat adalah sebagai berikut :

1. Melakukan identifikasi masalah yang digunakan sebagai pengaruh tulang punggung.

2. Melakukan identifikasi kategorikategori penyebab yang potensial terjadi.

3. Menambahkan cabang- cabang atau tulang pendukung yang dapat menunjukkan penyebab khusus

\section{HASIL DAN PEMBAHASAN}

Pengendalian Mutu Produk Akhir

SQC (Statistical Quality Control) merupakan salah satu metode yang dapat ditempuh untuk menerapkan pengendalian mutu. Pengendalian mutu menggunakan SQC pada penelitian ini dilakukan pada tahap akhir produk minyak telon diproduksi, sebelum produk didistribusi ke tangan konsumen. Keseluruhan proses pengendalian mutu pada PT X merupakan tanggung jawab dari bagian QC (Quality Control). Setelah proses selesai, hasil dari pemeriksaan mutu tersebut akan diserahkan kepada bagian QA (Quality Assurance) untuk dilakukan evaluasi dan perbaikan. Proses pemeriksaan yang dilakukan bagian QC (Quality Control) dimulai dari bahan baku diterima, proses produksi hingga dihasilkannya produk akhir serta penyimpanannya di gudang. 
PT X memiliki spesifikasi tertentu yang sudah ditetapkan untuk masingmasing produk yang diproduksi. Spesifikasi dari sebuah produk tersebut dapat dianggap sebagai standar dan uji secara fisik, kimia, ataupun mikrobiologi sehingga produk yang dihasilkan dapat didistribusikan dengan aman ke pasar. Spesifikasi yang diacu oleh PT $\mathrm{X}$ ini sesuai dengan standar BPOM mengenai minyak telon yang termasuk dalam kategori obat tradisional dengan jenis obat luar dalam sediaan cair. Cairan Obat Luar adalah sediaan Obat Tradisional berupa minyak, larutan, suspensi atau emulsi, terbuat dari simplisia atau ekstrak dan digunakan sebagai obat luar. Minyak telon termasuk dalam obat tradisioanal dengan sediaan cairan yang memiliki persyaratan mutu dari BPOM seperti pada Tabel 1.

Tabel 1. Persyaratan Mutu BPOM Minyak Telon

\begin{tabular}{ll}
\hline \multicolumn{1}{c}{ Parameter } & \multicolumn{1}{c}{ Standar } \\
\hline Angka Lempeng Total & $\leq 10^{5} \mathrm{koloni} / \mathrm{mL}$ \\
Staphylococcus aureus & Negative $/ \mathrm{mL}$ \\
Pseudomonas aeruginosa & Negative/mL \\
\hline Sumber $:$ BPOM $(2018)$ &
\end{tabular}

Sumber : BPOM (2018)

\section{Penyimpangan Produk Setelah Dikemas}

Setiap perusahaan mempunyai standar tertentu untuk setiap produk yang dihasilkan. Begitu pula PT $\mathrm{X}$ juga memiliki spesifikasi untuk produk yang dihasilkan. Produk yang menjadi fokus pada penelitian ini yaitu produk minyak telon. Dimana minyak telon merupakan produk campuran dari minyak adas, minyak kayu putih, dan minyak kelapa dengan takaran yang berbeda-beda. Minyak telon dan minyak sejenis ini termasuk dalam kategori fitofarmaka atau obat tradisional. Secara umum PT $X$ memiliki standar sesuai dengan Peraturan Kepala Badan Pengawas Obat Dan Makanan Republik Indonesia Nomor 12 Tahun 2014 Tentang Persyaratan Mutu Obat Tradisional. Dimana minyak telon termasuk dalam kategori obat luar dalam sediaan cair. Standar lolos minyak telon ini yaitu harus memiliki warna sedikit kuning dan jernih, kemudian memiliki aroma khas minyak telon, secara visual tidak ada kontaminasi benda asing serta beberapa spesifikasi lainnya dapat dilihat pada Tabel 2

Tabel 2. Spesifikasi Pemeriksaan Produk Jadi

\begin{tabular}{|c|c|c|}
\hline & Parameter & Spesifikasi \\
\hline \multirow[t]{4}{*}{1.} & $\begin{array}{l}\text { Pemerian } \\
\text { (Organoleptik) }\end{array}$ & \\
\hline & Bentuk & Cairan \\
\hline & Warna & $\begin{array}{ll}\text { Sedikit kuning } \\
\text { dan jernih }\end{array}$ \\
\hline & Rasa dikulit & Hangat dikulit \\
\hline & Uji Fitokimia & \\
\hline & Berat Jenis & $0,9000-0,9200$ \\
\hline & Indeks Bias & $1,4000-1,5000$ \\
\hline & $\begin{array}{l}\text { Uji Mikrobiologi } \\
\text { - Bakteri Patogen }\end{array}$ & \\
\hline & $\begin{array}{l}\text { Staphylococcus } \\
\text { aureus }\end{array}$ & Negative (-) \\
\hline & $\begin{array}{l}\text { Pseudomonas } \\
\text { aeruginosa }\end{array}$ & Negative (-) \\
\hline & $\begin{array}{l}\text { - Angka Lempeng } \\
\text { Total }\end{array}$ & $\leq 1,0 \times 10^{5}$ \\
\hline \multirow[t]{4}{*}{4.} & Volume & \\
\hline & - Vol rata-rata per botol & $75 \mathrm{ml}$ \\
\hline & $\begin{array}{l}\text { - Variasi keseragaman } \\
\text { volume }\end{array}$ & $75 \mathrm{ml} \pm 5 \%$ \\
\hline & - Keseragaman volume & $(95,00-105,00) \%$ \\
\hline
\end{tabular}

Sumber : PT X (2018)

Harga keripik kentang tergolong mahal, harga bahan mentah kentang untuk musim hujan danmusim kemarau juga berbeda. Pada musim hujan harga kentang Rp 2.500 per $\mathrm{kg}$, tetapi pada musim panas harga kentang Rp 4.000 per kg. Uniknya, perbedaan harga bahan mentah itu tidak mempengaruhi harga keripik kentang. Harga yang tetap sama juga berlaku untuk keripik kentang yang belum matang atau sudah matang. Sebab, $1 \mathrm{~kg}$ keripik kentang mentah. Selain kriteria produk yang dihasilkan, kemasan produk juga harus memiliki informasi yang lengkap seperti nama produk, deskripsi produk, komposisi, petunjuk pemakaian dan penyimpanan, berat bersih, keterangan 
produsen, nomor edar, nomor sertifikat halal, dan kode produksi. Kemasan yang digunakan untuk minyak telon adalah botol PET dengan bahan HD Blow. Pada proses pengemasan produk ini akan beberapa kali melewati tahap inspeksi. Tahap inspeksi merupakan suatu proses pengecekan pada kemungkinan adanya penyimpangan pada produk misalnya terdapat benda asing, kecacatan pada koding, kemasan dan label produk. Pada proses pengkodingan, operator melakukan pengecekan pada kode produksi dan exp terkait posisi koding yang dicetak, ketebalan tinta, serta kesesuaian kode produksi dan exp. Selanjutnya pada proses pelabelan operator juga melakukan pengecekan terkait posisi label yang ditempelkan. Penempelan label yang miring ataupun kelebihan bahan perekat akan dilakukan tindakan dengan melepas label yang melekat dan menggantinya dengan label yang baru. Pada proses shrink juga dilakukan pengecekan pada plastik yang hasil proses shrink. Plastik hasil proses shrink yang melekat pada inner dus harus menutup ujung dari inner dus.

Penyimpangan produk atau produk cacat sangat sering menjadi masalah bagi banyak industri terutama industri besar. Sebagian besar cacat produk terjadi karena kesalahan mesin, manusia, metode dan bisa saja karena material bahan baku yang digunakan. Produk yang cacat mempunyai kemungkinan untuk masuk ke pasaran. Hal tersebut dapat disebabkan karena kurangnya pengendalian mutu, monitoring maupun proses controlling pada produk. Oleh sebab itu, PT X selalu melakukan pendataan kecacatan produk selama produksi berlangsung. Fungsi dari data penyimpangan ini dilakukan agar data ini dapat menjadi acuan bagi perusahaan untuk memperbaiki sistem produksinya.

\section{Menentukan Prioritas Perbaikan (Diagram Pareto)}

Salah satu tools yang sering digunakan dalam hal pengendalian mutu adalah Diagram Pareto, yang bertujuan untuk mengidentifikasi kesalahan yang dominan dalam produk akhir minyak telon. Diagram Pareto merupakan grafik batang yang menunjukkan masalah berdasarkan urutan banyaknya jumlah kejadian dari jumlah permasalahan yang paling banyak terjadi sampai yang paling sedikit terjadi. Sehingga diagra pareto adalah alat yang dapat merepresentasikan sumber kecacatan produk yang paling sering ditemui, jenis kecacatan produk yang paling sering muncul, ataupun alasan-alasan yang paling sering muncul. Sehingga alat tersebut dapat membantu perusahaan mengidentifikasi penyebab kecacatan terbesar agar dapat dilakukan perbaikan. Data kerusakan produk Minyak Telon pada bulan Desember 2017 di PT X ditunjukkan pada Tabel 3.

Tabel 3. Data Jenis Cacat, jumlah cacat dan prosentase cacat produk minyak telon

\begin{tabular}{lllc}
\hline No & Jenis Cacat & $\begin{array}{l}\text { Jumlah } \\
\text { Cacat }\end{array}$ & $\begin{array}{c}\text { \% } \\
\text { Cacat }\end{array}$ \\
\hline 1 & Volume Kurang & 1203 & $54,8 \%$ \\
2 & Expired Date & 631 & $28,8 \%$ \\
3 & Tutup Tidak & 267 & $12,2 \%$ \\
& Rapat & 78 & $3,6 \%$ \\
4 & Label Miring & 13 & $0,6 \%$ \\
5 & Dus Basah & $\mathbf{2 1 9 2}$ & $\mathbf{1 0 0}$ \\
\hline
\end{tabular}

Tabel 3 menunjukkan bahwa dari karakteristik kualitas produk minyak telon yang dihasilkan pada bulan Desember tahun 2017 adalah volume produk yang tidak sesuai standar yaitu sebanyak 1203 produk atau sekitar 54,8\%. Berdasarkan Gambar 1 indikator kualitas volume produk yang tidak sesuai standar mencerminkan bahwa pengendalian yang dilakukan perlu untuk dioptimalkan, karena kuantitas dan kualitas produk minyak telon berdampak pada 
ketidakpuasan konsumen terhadap produk yang akan berpengaruh pada keuntungan yang diperoleh perusahaan.

Gambar 1. Diagram Pareto berdasarkan kecacatan produk pada bulan Desember 2017

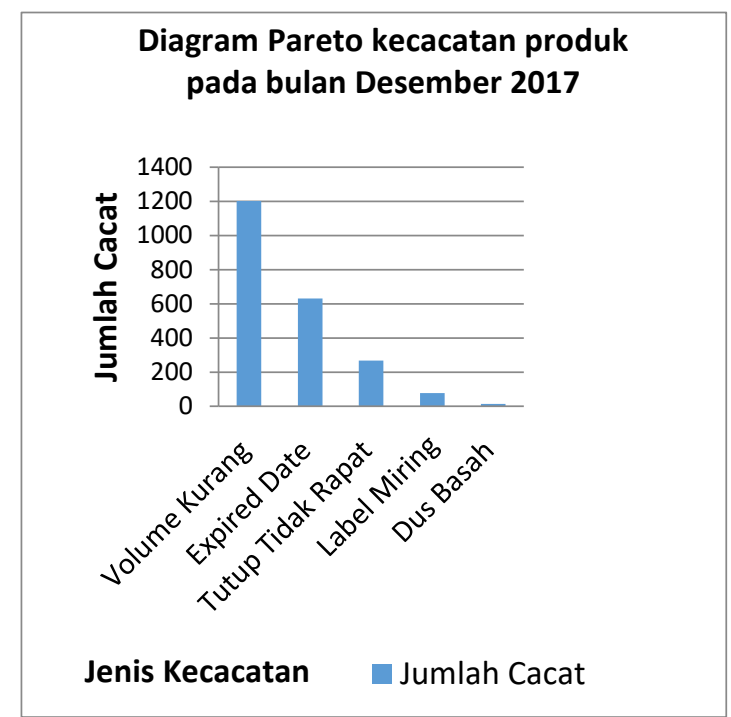

Setelah data terkumpul, jenis kecacatan diurutkan sesuai dengan besarnya nilai frekuensi dari yang tertinggi sampai dengan yang terendah. Data dan jenis yang telah diurutkan dapat dilihat pada Tabel 4.

Tabel 4. Urutan kecacatan produk minyak telon PT X pada bulan Desember 2017

\begin{tabular}{|c|c|c|c|c|c|}
\hline ż & 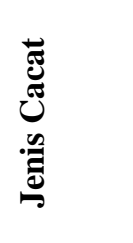 & 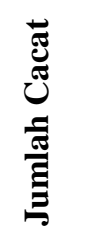 & 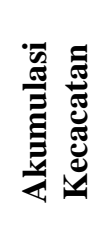 & שٓ & 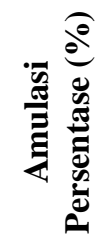 \\
\hline 1 & $\begin{array}{l}\text { Volume } \\
\text { Kurang }\end{array}$ & 1203 & 1203 & 54,8 & 54,8 \\
\hline 2 & $\begin{array}{l}\text { Expired } \\
\text { Date }\end{array}$ & 631 & 1834 & 28,8 & 83,6 \\
\hline 3 & $\begin{array}{l}\text { Tutup } \\
\text { Tidak } \\
\text { Rapat }\end{array}$ & 267 & 2101 & 12,2 & 95,8 \\
\hline 4 & $\begin{array}{l}\text { Label } \\
\text { Miring }\end{array}$ & 78 & 2179 & 3,6 & 99,4 \\
\hline 5 & $\begin{array}{l}\text { Dus } \\
\text { Basah } \\
\text { Total }\end{array}$ & $\begin{array}{l}13 \\
2192\end{array}$ & 2192 & $\begin{array}{l}0,6 \\
\mathbf{1 0 0}\end{array}$ & 100 \\
\hline
\end{tabular}

Dari Tabel 4 diatas dapat diketahui bahwa total kecacatan produk adalah 2192 dengan volume kurang menjadi kecacatan tertinggi dengan persntase 54,8 \%. Data urutan kecacatan produk minyak telon PT $X$ pada bulan Desember 2017 ini kemudian disusun menjadi diagram pareto untuk mengetahui permasalahan yang menjadi prioritas bagi PT $\mathrm{X}$ yang perlu untuk diselesaikan. Gambar diagram pareto kecacatan produk akhir minyak

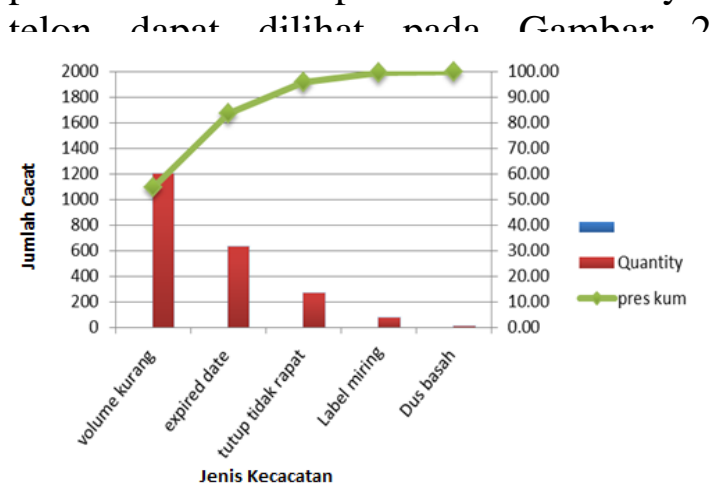

Gambar 2. Diagram Pareto kecacatan produk minyak telon

Berdasarkan diagram pareto yang dihasilkan, dapat diketahui bahwa faktor terbesar penyebab kecacatan adalah volume kurang dan faktor terkecil adalah dus yang basah. Jumlah total kecacatan selama produksi Minyak Telon pada bulan Desember 2017 adalah sebesar 2192 yang didapat dari data kerusakan pada beberapa batch produksi. Data tersebut menunjukkan bahwa tingkat kecacatan yang terjadi pada produksi Minyak Telon di bulan Desember 2017 masih dalam kategori wajar. Lebih dari $80 \%$ adanya defect disebabkan kerena volume yang kurang dang permasalahan pada Expired Date. Oleh karena itu, analisis perbaikan mutu perlu dilakukan untuk mengatasi cacat tersebut.

Rucitra (2014) dalam penelitiannya menyatakan bahwa Penciptaan produk dengan volume pada masing-masing kemasan sama akan berdampak pada harga jual yang ditentukan. Ningtyas 
(2009) juga menyatakan bahwa konsumen saat ini semakin teliti dan selektif dalam pembelian produk, khususnya untuk produk makanan, konsumen tidak hanya menilai dari cita rasanya saja tetapi juga dari variasi kemasan, jenis kemasan, serta kestabilan kualitas dan volume pada masing-masing produk yang mereka konsumsi. Label merupakan suatu bagian dari sebuah produk yang membawa informasi verbal tentang produk atau penjualnya. Menurut Tjiptono (2002) menyatakan bahwa label merupakan bagian dari suatu produk yang menyampaikan informasi mengenai produk dan penjual. Sebuah label biasa merupakan bagian dari kemasan, atau bisa pula merupakan etiket (tanda pengenal) yang terdapat pada produk. Sedangkan Kotler (2000) menyatakan bahwa label adalah tampilan sederhana pada produk atau gambar yang dirancang dengan rumit yang merupakan satu kesatuan dengan kemasan. Label bisa hanya mencantumkan merek atau informasi. Begitu juga dengan label expired date, apabila label tersebut tidak sesuai dengan tanggal produk tersebut diproduksi maka akan berdampak pada ketidaksesuaian informasi pada kemasan yang dapat merugikan konsumen.

\section{Fishbone Diagram}

Diagram tulang ikan atau Fishbone Diagram adalah salah satu metode untuk meningkatkan kualitas. Sering juga diagram ini disebut dengan diagram sebab-akibat atau cause effect diagram. Fishbone diagram (diagram tulang ikan) memiliki fungsi dalam yaitu untuk mengidentifikasi penyebab-penyebab yang kemungkinan timbul dari suatu efek spesifik. Metode ini juga digunakan menampilkan unsur-unsur yang mengakibatkan produk tidak sesuai dengan parameter mutu yang sudah ditentukan.

Berdasarkan data observasi selama penelitian di PT X, ternyata masih sering dan banyak ditemukan kerusakan produk yang disebabkan oleh beberapa faktor terutama kegagalan saat proses pengemasan. Untuk menghindari dan mencegah defect yang sama, maka harus ada evaluasi mengenai faktor-faktor penyebab defect. Evaluasi dapat dilakukan berdasarkan faktor material, tenaga kerja, metode serta mesin dan peralatan dengan menggunakan diagram tulang ikan. Diagram tulang ikan untuk analisis penyebab defect volume yang kurang ditunjukkan pada Gambar 2 dan penyebab defect pada permasalahan kode expired date yaitu karena kesalahan cetak kode ditunjukkan pada Gambar 3.

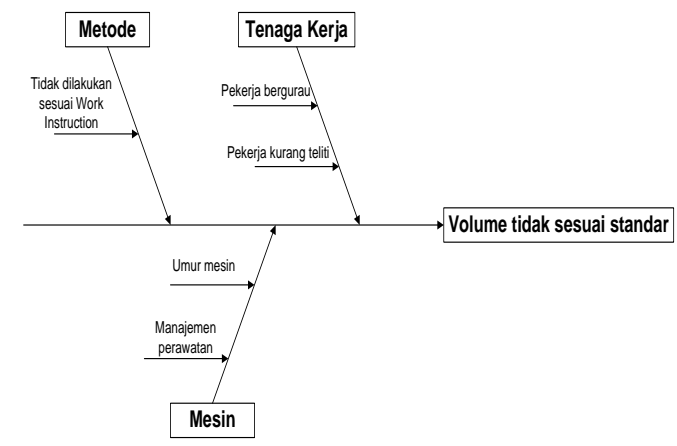

Gambar 2. Diagram Tulang Ikan (Volume Kurang)

Berdasarkan analisis yang dilakukan dengan menggunakan diagram tulang ikan, diketahui beberapa faktor yang menyebabkan volume kurang yaitu :

1) Metode

Metode merupakan prosedur kerja dimana setiap keryawan harus melakukan instruksi kerja sesuai dengan prosedur yang telah ditetapkan pada Work Instruction (WI). Metode pengemasan yang tidak dilakukan dengan benar dapat mengakibatkan penurunan kualitas produk yang dihasilkan. Proses dan metode setting awal sangat berpengaruh terhadap terjadinya defect, proses dan metode tersebut sebenarnya telah memiliki Standar Operasional Prosedur (SOP) namun jika masih ada kasus saat hasil filling dengan volume yang tidak sesuai 
standar, dapat dikatakan bahwa proses pengaturan awal mesin tidak sesuai dengan SOP. Moekijat (2008) menyatakan bahwa SOP merupakan urutan langkahlangkah (pelaksanaan pekerjaan) dimana pekerjaan tersebut dilakukan, bagaimana cara melakukannya, dimana melakukannya, dan siapa yang harus melakukan. Sehingga setiap metode yang dilakukan dalam setiap proses harus berdasar pada SOP yang telah dibuat sebelumnya.

2) Tenaga Kerja

Tenaga kerja merupakan faktor yang sangat mungkin menjadi penyebab kontaminasi dan kecacatan produk. Penyebab terbesar juga terjadi karena volume yang tidak sesuai standar, hal ini juga dapat disebabkan karena faktor manusia. Wijayanti (2009) menyatakan bahwa tenaga kerja merupakan orang yang mampu melakukan pekerjaan untuk menghasilkan barrang/jasa, dengan tujuan untuk memenuhi kebutuhan sendiri maupun untuk masyarakat. Tenaga kerja pada PT X dapat menjadi salah satu penyebab kegagalan produk, misanya pada saat pengaturan awal mesin pekerja tidak melakukan sesuai prosedur yang ditetapkan. Selain itu pada saat inspeksi pekerja memeriksa volume pada botol hasil proses filling sembari bergurau, sehingga botol hasil filling yang seharusnya tidak lolos dapat masuk ke proses capping. Melakukan pekerjaan dengan bergurau menyebabkan karyawan tidak teliti dalam memeriksa keseragaman volume pada proses filling.

\section{3) Mesin}

Setelah dilakukan analisis pada setiap masing-masing faktor, terdapat faktor lain yang dapat menyebabkan ketidak sesuaian volume pada produk adalah dari segi mesin. Jarwo (2006) menyatakan bahwa mesin merupakan alat mekanik atau elektrik yang mengirim atau mengubah energi untuk melakukan atau membantu pelaksanaan tugas manusia. Pada segi mesin, faktor yang berpengaruh adalah umur mesin yang sudah tua membuat kinerja dari mesin sendiri tidak optimal. Selain itu maintenance atau perawatan pada mesin mempengaruhi kinerja dari mesin. Mesin-mesin dan perlatan yang dioperasikan dalam perusahaan cenderung semakin kompleks dan membutuhkan modal besar untuk investasi awal maupun untuk biaya operasional.

Untuk itu mesin yang kurang perawatan akan mengakibatkan penurunan kualitas produk. Hal tersebut dapat diketahui dari unsur umur masing-masing mesin yang digunakan setiap harinya agar tidak sering terjadi kerusakan atau kegagalan dama pengoperasian sehingga perlu dilakukan perawatan secara rutin. Priyanta (2000) menambahkan bahwa perawatan mesin yang tidak rutin dilakukan dan dikombinasikan dengan manajemen pemeliharaan yang terabaikan maka akan berdampak pada pendeknya masa guna mesin (useful life) serta menambah biaya kerusakan (downtime cost) yang timbul akibat dampak dari kerusakan sistem.

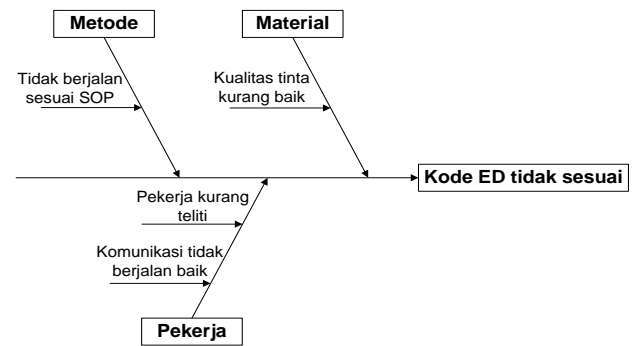

\section{Gambar 3. Diagram Tulang Ikan (Expired date produk)}

Berdasarkan analisis yang dilakukan dengan menggunakan diagram tulang ikan, diketahui beberapa faktor yang menyebabkan kesalahan pada kode ED (Expired date) yaitu :

\section{1) Pekerja}

Hal yang sangat mungkin menjadi penyebab kontaminasi dan kerusakan adalah pekerja. Pekerja yang bekerja terutama di ruangan produksi lebih 
banyak sebagai inspector dan pelaksana SOP. Pekerja di PT $\mathrm{X}$ terus menerus melihat dan mengamati dan memeriksa kode Expired Date sesuai dengan ketentuan. Hal tersebut dilakukan karena mesin coding yang digunakan belum ada sensor untuk mendeteksi kesesuaian kode Expired Date yang dicetak. Proses tersebut dapat menyebabkan mata pekerja kelelahan sehingga tidak semua label pada proses coding diperiksa dengan teliti. Kode Expired Date yang tidak sesuai dengan kode batch juga disebabkan oleh informasi atau perintah pencetakan kode yang salah dari atasan. Sehingga perlunya komunikasi yang baik antara pekerja agar informasi yang disampaikan sesuai.

2) Material

Kualitas produk akhir juga ditentukan dari kualitas bahan baku yang digunakan, sehingga terdapat istilah "Quality at the Source" yang berarti kualitas produk yang dihasilkan sangat bergantung dari kualitas bahan baku yang digunakan. Material atau bahan baku dapat menjadi penyebab defect karena berbagai hal. Pencetakan kode produksi di PT X menggunakan Ink Jet Print dan telah memiliki prosedur/SOP dalam pengecekan tinta yang menjadi bahan untuk mencetak kode Expired Date. Akan tetapi pernah terjadi keburaman warna pada hasil cetakan. Hal tersebut dapat disebabkan karena kualitas bahan baku dari supplier mengalami penurunan mutu. Tanggal expired date atau tanggal kadaluwarsa berguna untuk memberikan informasi terkait waktu dan tanggal produk tersebut masih memenuhi syarat mutu dan keamanan untuk dikonsumsi. Apabila hasil cetakan dari tanggal kadaluarsa atau ED tidak terlihat maka akan mempengaruhi konsumen untuk melakukan pembelian.

3) Metode

Metode merupakan prosedur kerja dimana setiap pekerja harus melakukan prosedur kerja sesuai Work Instruction (WI) yang sudah ditetapkan. WI merupakan standar dari metode yang harus dan akan dilakukan oleh pekerja, agar dapat menghasilkan produk sesuai yang ditetapkan. Namun kesalahan pada WI dapat mengakibatkan penurunan kualitas produk yang dihasilkan. Metode pengisian tinta cetak dan perawatan mesin juga sangat berpengaruh terhadap terjadinya defect, proses dan metode tersebut sebenarnya sudah memiliki WI. Sehingga apabila masih ada kasus saat hasil cetakan kurang baik atau kesalahan tanggal cetak, berarti proses pengisian tinta, perawatan mesin ataupun penyampaian tanggal kode Expired Date produk tidak berjalan sesuai dengan Work Instruction.

\section{KESIMPULAN}

PT X menerapkan pengendalian mutu, hal tersebut diterapkan untuk menjaga kualitas mutu minyak telon agar tetap baik. Pengendalian mutu produk pada saat proses pengemasan juga penting untuk diterapkan karena untuk menjaga kualitas mutu dari produk. Adapun proses yang dilakukan untuk menjaga produk tetap dalam kualitas yang baik antara lain pada saat penerimaan bahan baku, proses produksi, proses pengemasan dan penyimpanan serta pendistribusian produk hingga sampai ke tangan konsumen.

\section{SARAN}

Saran yang dapat diberikan kepada PT X yaitu dengan melakukan perbaikan mesin filling agar volume yang dihasilkan konstan sesuai spesifikasi. Dan melakukan perbaikan terhadap beberapa penyebab defect dengan menggunakan metode Plan, Do, Check, dan Action. Serta perlu dilakukan pemeriksaan produk kembali pada bagian quality control sebelum produk didistribusikan kepada konsumen saat produk disimpan di dalam gudang finish good.

\section{DAFTAR PUSTAKA}


Jarwo P. 2006.Elemen Mesin Dasar.

Quality Improvement Strategy Jurusan Pendidikan Teknik Mesin Using integration Quality Function FT UNY. Yogyakarta

Kotler. 2000. Manajemen Pemasaran edisi 2. Prenhallindo. Jakarta

Moekijat. 2008. Manajemen Personalia dan Sumber Daya Manusia. BFFE. Yogyakarta

Deployment (QFD) With Analytical Hierarchy Process (AHP). Indonesian Green Technology Journal

Sumhudi, A. 1991. Komposisi Desain Riset. Ramadhani.Solo

Priyanta. D. 2000. Keandalan dan Perawatan. Teknik Sistem Perkapalan. Institut Teknologi Sepuluh November. Surabaya.

Rucitra. 2014. Analysis of Consumers Satisfaction and Jackfruit Chips

Tjiptono Angipora. 2002. Dasar-Dasar Pemasaran. PT. Raja Grafindo Persada. Jakarta

Wijayanti A. 2009.Hukum Ketenagakerjaan Pasca Reformasi. Sinar Grafika. Jakarta 